\title{
GENETIC RELATIONSHIP BETWEEN TORAJANESE LANGUAGE AND MANDARESE LANGUAGE
}

\author{
Rabiatul Adawiah ${ }^{1}$, Desfi Nira Sari ${ }^{2}$ \\ UIN Alauddin Makassar \\ ${ }^{1}$ raratwentyon3@gmail.com \\ ${ }^{2}$ desvyaa@gmail.com
}

\begin{abstract}
Some codices state that ancestors of South and West Sulawesi people come from Toraja area. It drives to a logic thinking that Torajanese is protolanguage of other local languages such as Makassarese. Buginese and Mandarese. This research is aimed to investigate the genetic relationship between Torajanese and Mandarese and to identify kinds of sound change happening from Torajanese into Mandarese. The method used in this paper is lexicostatistics by comparing 200 Swadesh basic vocabulary of Torajanese and Mandarese. The result shows that Torajanese and Mandarese can be categorized as two relative languages with kinship percentage rate of $49 \%$. The second finding is that there are eight patterns of sound changes; they are apharesis, syncope, lenition, fortition, assimilitaion, vowel breaking, metathesis and prosthesis.
\end{abstract}

Keywords: genetic relationship, Torajanese, Mandarese

\begin{abstract}
Abstrak
Beberapa naskah kuno menyatakan bahwa nenek moyang berbagai suku yang berada di wilayah Sulawesi Selatan dan Sulawesi Barat berasl dari Toraja. Hal tersebut melahirkan sebuah pemikiran logis bahwa bahasa Toraja merupakan bahasa proto dari bahasa local lainnya seperti Makassar, Bugis dan Mandar. Penelitian ini bertujuan untuk mengetahui hubungan genetik antara bahasa Toraja dan bahasa Mandar dan untu mengidentifikasi perubahan bunyi dari bahasa Toraja dan bahasa Mandar. Penelitian ini menggunakan metode leksikostatistik dengan membandingkan 200 kata dasar Swadesh dari kedua bahasa tersebut. Hasil penelitian menujukkan bahwa bahasa Toraja dan bahasa Mandar dapat dikategorisasikan sebagai bahasa yang berkerabat dengan persentasi kemiripan sebesar $49 \%$ atau memiliki perbedaan sebesar $51 \%$ saja. Kedua, terdapat delapan jenis perubahan bunyi pada dua bahasa tersebut yakni syncope, lenition, fortition, assimilitaion, vowel breaking, metathesis dan prosthesis.

Kata kunci: hubungan genetic, Toraja, Mandar
\end{abstract}

\section{RESEARCH BACKGROUND}

Languages belonging to the Austronesian language family have long been an interesting field of study for experts in the field of comparative historical linguistics. The vast languages of its spreading in the world have invited the curiosity of linguists from different parts of the world to further explore its origins. Even Samantho (2015) relates the findings of Austronesian language as a proto-language proposed by Keraf (1991) with the assumption that Austronesian society is occupant of the lost Atlantis. 
Although the existence of Austronesian society is still debated between fact and fiction (Masinambouw, et al, 2004: 447), but the study of genealogy and kinship and its traces in the languages of the archipelago is experiencing rapid development. Some words are equally stable, for example the word for eyes in many Austronesian languages is "eye" also starting from the northernmost language in Taiwan to the southernmost language in Aotearoa.

In support of the above discovery, in specific way some ancient manuscripts also state that the ancestors of various tribes in the region of South Sulawesi and West Sulawesi came from Toraja. It gave birth to a logical thinking that the Toraja language is a proto language of other local languages such as Makassar, Bugis and Mandar. Not only that, the inhabitants of most areas of Central Sulawesi are also believed to have originated from Toraja (Salombe in Yatim and Machmoed, 9999). Then, the Toraja is classified into some types: Eastern Toraja settled in Poso; West Toraja settled in Parigi; and South Toraja or known as Toraja Saqdan settled in the area of South Sulawesi and West Sulawesi as areas along the Saqdan river. Darmawati (2014) has proved that Kaili as local language in Parigi has kinship percentage rate of $42.5 \%$ with Torajanese. Based on these findings, the researchers also are interested in tracking Toraja language in Mandar language using 200 Swadesh vocabulary. The researchers hope that the result of this research could be a reference to keep maintaining the kinship between Mandarese and Torajanese in order to avoid any conflict in society.

\section{REVIEW OF HISTORICAL COMPARATIVE LINGUISTICS}

Historical Comparative Linguistics is a branch of linguistic science that examines language development from one time to another, looking at the ways in which languages change, studying the causes and effects of discussion and revealing the relationships of languages both within the same family and the clump different.

In general, there are two methods that can be used in Historical Linguistics Comparative research. The first is the quantitative method with the lexicostatistic technique. This method is used to find or determine the kinship of the language. Thus, the results will show a glimpse of the historical relation rankings of kinship relationships. In this quantitative method, the instrument is the 200 basic vocabulary that Swadesh has formulated.

The second method is qualitative using reconstruction techniques. The second method aims to group or classify languages by finding correspondence between languages that are related. Reconstruction can be done internally to search for protolanguage from branches of languages. Meanwhile, external reconstruction is performed after obtaining the results of quantitative lexicostatistic research.

One of the changes that can become an object in this study is the change that occurs in the sound of the language. Crowley (1997) categorizes sound languages into nine types. They are: 


\begin{tabular}{|c|c|c|}
\hline Types of Changes & Definiton & Example \\
\hline Lenition & $\begin{array}{l}\text { Lenition is a kind of } \\
\text { changes from the stronger } \\
\text { sounds into the weaker } \\
\text { sounds. Related to vibrate } \\
\text { systems in sounds } \\
\text { producing, lenition may } \\
\text { happen from voiced sound } \\
\text { into voiceless sounds. } \\
\text { Crowley (1997) designs a } \\
\text { generalization of lenition } \\
\text { forms, namely; } \\
\text { a }>\text { e o }>\mathrm{i}>\text { rhotics }> \\
\text { laterals }>\text { nasals }>\text { voiced } \\
\text { fricatives > voiceless } \\
\text { fricatives > voiced stops > } \\
\text { voiceless stops. }\end{array}$ & $\begin{array}{rr}\text { Stronger } & \text { Weaker } \\
\mathrm{b} & \mathrm{p} \\
\mathrm{p} & \mathrm{f} \\
\mathrm{f} & \mathrm{h} \\
\mathrm{x} & \mathrm{h} \\
\mathrm{b} & \mathrm{W} \\
\mathrm{v} & \mathrm{w} \\
\mathrm{a} & \mathrm{\partial} \\
\mathrm{d} & 1 \\
\mathrm{~s} & \mathrm{r} \\
\mathrm{k} & ? \\
\mathrm{i} & \dot{\mathrm{i}}\end{array}$ \\
\hline Fortition & $\begin{array}{l}\text { Fortition is the opposite of } \\
\text { lenition. It covers the } \\
\text { change from weaker } \\
\text { sounds into stronger sound. }\end{array}$ & $\begin{array}{l}\text { EnglishTokPisin } \\
\text { Naif } \longrightarrow \text { Naip }\end{array}$ \\
\hline Aphaeresis & $\begin{array}{l}\text { Aphaeresis is a kind of } \\
\text { changes where initial } \\
\text { segments are dropped. }\end{array}$ & \begin{tabular}{ll} 
& \multicolumn{2}{c}{ Angkamuthi } \\
$*_{\text {maji }} \longrightarrow$ aji & 'food' \\
$*_{\text {nani }} \longrightarrow$ ani & 'ground'
\end{tabular} \\
\hline Apocope & $\begin{array}{l}\text { Apocope is the term for a } \\
\text { change where word final } \\
\text { segments are dropped. }\end{array}$ & $\begin{array}{l}\text { Southeast Ambryn } \\
* \text { utu } \longrightarrow \text { ut } \quad \text { 'lice' } \\
* \text { use } \longrightarrow \text { us } \quad \text { 'rain' }\end{array}$ \\
\hline Syncope & $\begin{array}{l}\text { Syncope refers to the loss } \\
\text { of segments in the middle } \\
\text { of words. }\end{array}$ & $\begin{array}{l}\text { Lenakel } \\
*_{\text {nalimana }} \longrightarrow \text { nelmin 'hand' } \\
* \text { masa } \longrightarrow \text { mha 'tide' }\end{array}$ \\
\hline Cluster Reduction & $\begin{array}{l}\text { Consonant cluster is when } \\
\text { consonats stand side by } \\
\text { side without any vowels } \\
\text { between them. Sometime } \\
\text { people delete one of those } \\
\text { consonants, and it is called } \\
\text { as cluster reduction. }\end{array}$ & $\begin{array}{l}\text { Cluster reduction takes place } \\
\text { from Old English into Modern } \\
\text { English. For instace, bomb used } \\
\text { to be pronunced with [mb] in } \\
\text { word ending; but today it is } \\
\text { pronunced with [bom]. }\end{array}$ \\
\hline
\end{tabular}




\begin{tabular}{|c|c|c|}
\hline Haplology & $\begin{array}{l}\text { Haplology refers to the loss } \\
\text { of an entire syllable when } \\
\text { that syllable is identic with } \\
\text { the next syllable. }\end{array}$ & $\begin{array}{l}\text { The word England come from } \\
\text { the word Anglaland (land of } \\
\text { Angles, group of people who } \\
\text { settled in Britain over } 1000 \\
\text { years ago). There two identical } \\
\text { syllables namely la, and one of } \\
\text { them was reduced. }\end{array}$ \\
\hline Excrescence & $\begin{array}{l}\text { Excrencence is a change } \\
\text { when a consonant is put } \\
\text { between two consonant } \\
\text { cluster. }\end{array}$ & $\begin{array}{l}\text { English } \\
* æ a m t i g \longrightarrow \text { empti } \\
* \text { Oymle } \longrightarrow \text { Oimbl }\end{array}$ \\
\hline Ephenthesis & $\begin{array}{l}\text { Ephenhesis refers to a } \\
\text { change when putting a } \\
\text { vowel between two } \\
\text { consonants in a cluster. }\end{array}$ & 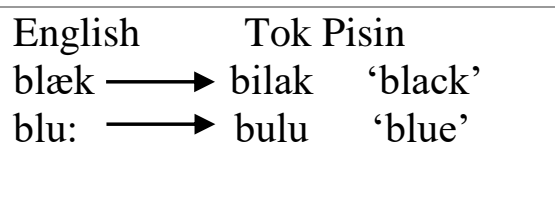 \\
\hline Prothesis & $\begin{array}{l}\text { Prothesis is another term } \\
\text { used to refer to a particular } \\
\text { type of addition. The } \\
\text { addition of sound at the } \\
\text { beginning od a word. }\end{array}$ & $\begin{array}{l}\text { Motu } \\
*_{\text {api }} \stackrel{\text { lahi }}{\longrightarrow} \quad \begin{array}{l}\text { "fire' } \\
\text { *au lau }\end{array} \quad \text { "I, me" }\end{array}$ \\
\hline Metathesis & $\begin{array}{l}\text { Methatesis is a fairly } \\
\text { uncommon kind of change. } \\
\text { It does not involve either } \\
\text { the loss or addition of } \\
\text { sounds or a change in the } \\
\text { appearance of a particular } \\
\text { sound; it is simply a } \\
\text { change in the order of the } \\
\text { sounds. }\end{array}$ & 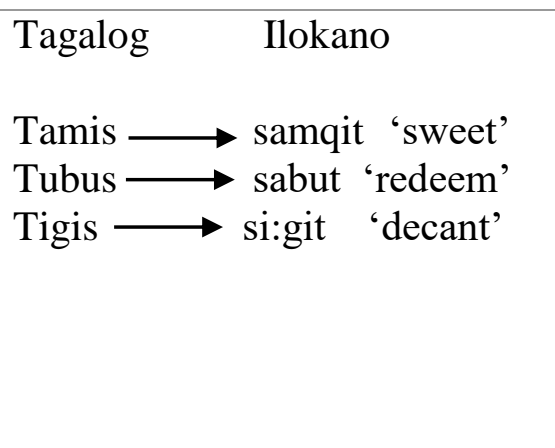 \\
\hline Fusion & $\begin{array}{l}\text { Fusion is a fairly frequent } \\
\text { kind of siund change, in } \\
\text { which two originally } \\
\text { separate sounds become a } \\
\text { single sound. The resulting } \\
\text { single sound carries some } \\
\text { of the features of both of } \\
\text { the original sounds. }\end{array}$ & $\begin{array}{l}\text { Attic Greek } \\
{ }^{*} \mathrm{~g}^{\mathrm{w}} \text { ous } \longrightarrow \text { bous } \\
{ }^{*} \mathrm{~g}^{\mathrm{w}} \text { atis } \longrightarrow \text { basis }\end{array}$ \\
\hline
\end{tabular}




\begin{tabular}{|c|c|c|}
\hline Unpacking & $\begin{array}{l}\text { Unpacking is a phonetic } \\
\text { process that is just the } \\
\text { opposite of phonetic } \\
\text { fusion. from a single } \\
\text { original sound, a sequence } \\
\text { of two sounds may } \\
\text { develop, each with some of } \\
\text { the features of the original } \\
\text { sound. }\end{array}$ & 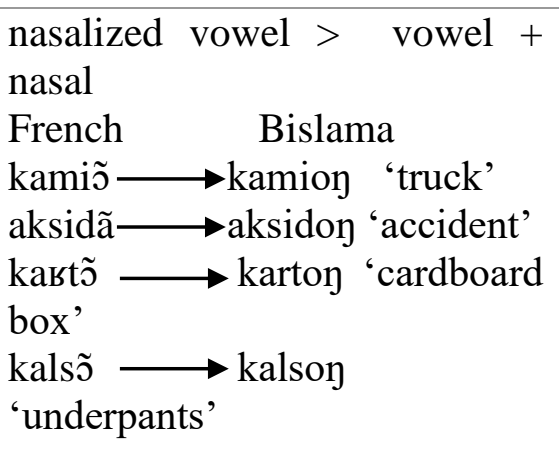 \\
\hline Vowel Breaking & $\begin{array}{l}\text { Vowel breaking in the } \\
\text { change known a vowel } \\
\text { breaking, a singe vowel } \\
\text { changes to become a } \\
\text { diphtong, with the original } \\
\text { vowel remaining the some } \\
\text { but with a glide of some } \\
\text { kind being added, either } \\
\text { before or after it. }\end{array}$ & $\begin{array}{l}\text { Kairiru } \longrightarrow \\
\text { *pale } \longrightarrow \text { pial } \\
\text { *manuk } \longrightarrow \text { mian } \\
\text { *ranum } \longrightarrow \text { rian 'bouse' 'ward' } \\
\text { *lako } \longrightarrow \text { liak 'go' }\end{array}$ \\
\hline Assimilation & $\begin{array}{l}\text { When one sound causes } \\
\text { another sound to change so } \\
\text { that the two sounds end up } \\
\text { being more similiar to each } \\
\text { other in some way, we call } \\
\text { this assimilation }\end{array}$ & 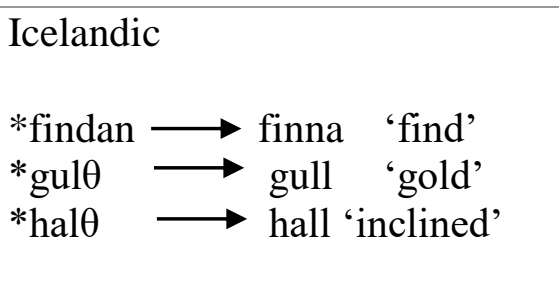 \\
\hline Dissimilation & $\begin{array}{l}\text { Dissimilation means that } \\
\text { one sound changes to } \\
\text { become less like some } \\
\text { other nearby sound. }\end{array}$ & $\begin{array}{l}\text { Afrikaans } \\
*_{\text {sxo:n } \longrightarrow \text { sko:n 'clean' }} \longrightarrow \text { skælt 'debt' }\end{array}$ \\
\hline $\begin{array}{l}\text { Abnormal } \\
\text { Changes }\end{array}$ & $\begin{array}{l}\text { Abnormal changes is a } \\
\text { linguistic change which is } \\
\text { both rare hard to imagine a } \\
\text { motivation or pathway for. }\end{array}$ & 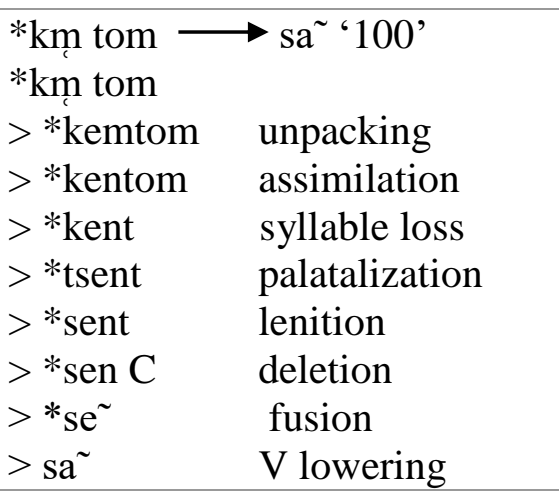 \\
\hline
\end{tabular}




\section{HISTORICAL RELATIONSHIP OF TORAJANESE AND MANDARESE}

According to folklore, Tana Toraja is considered the oldest inhabitants of Sulawesi. From the transliteration of the old text or codices such as Pattodioloang and Lagaligo (Digital Version from Leiden University, 2017), it can be drawn a similarity of the story of the origin of Toraja, Mandar, Bugis and Makassar as cultures. Puang Matoa (The supreme God) in the heavens first sent Tamboro-Langi to rule human life on this world. Tamboro Langi is trusted by Torajans as a mover "Aluk Tudolo" (the rules of the ancients considered as religions). Tamboro 'Langi arrived at the summit of Lantimojong, narrated that at that time the largest part of the mainland of South Sulawesi was still inundated with water. What appears at sea level is just the top of Bawakaraeng mountain in the south. Next, Tamboro Langi mates with a woman from the Sa'dan river named Lando Belua. The descendants of Tamboro-Langi and Lando Belua then spread to various regions of South Sulawesi and West Sulawesi, and formed a group now known as Mandar, Bugis and Makassar.

\section{METHODOLOGY}

This research used descriptive quantitative method. To collect the data, the researchers used interview technique. The researchers interviewed someone who uses Mandarese as her daily language and another one who uses Torajanese as her daily language too. They should be adult, and live in their hometown.

To analyze the data, the researchers used Lexicostatistic technique by Keraf (1991) and categories of sound changes by Crowley (1997). Lexicostatistics is an approach to comparative linguistics that involves quantitative comparison of lexical cognates. According to Keraf (1991) Lexicostatistic is a grouping technique that is more likely to give priority to observation of the words (Lexicon) as statistisc for then trying to assign the grouping was based on the presentation of the similarities and differences of one language with another language. The formula of lexicostatistics as:

$\mathrm{D}=\mathrm{S} / \mathrm{N} \times 100 \%$

Where:

$\mathrm{D}=$ Lexicon difference

$\mathrm{S}=$ The number of diferent lexicon

$\mathrm{N}=$ Number of words compared

After finding the total of lexicon differences, the researchers will measure the kinship of Mandarese and Torajanese based on these criteria:
$81 \%$ to up
: Language differences
$51-80 \%$
: Dialect differences
$31-50 \%$
: Subdialect differences
$21-30 \%$
: Speech differences
below $20 \%$
: There is no difference 


\section{FINDINGS}

a. Pair of Identical Words

\begin{tabular}{|c|c|c|c|c|c|}
\hline Number & Code & English & Indonesian & Torajanese & Mandarese \\
\hline 1 & 1 & Ashes & Abu & $\mathrm{Abu}$ & $\mathrm{Abu}$ \\
\hline 2 & 2 & Water & Air & Uai & Wai \\
\hline 3 & 3 & Root & Akar & Waka' & Uwake' \\
\hline 4 & 4 & I & Aku & Aku' & Iau \\
\hline 5 & 5 & Flow & Alir (meng-) & Lolong & Lolong \\
\hline 6 & 7 & Wind & Angin & Angin & Anging \\
\hline 7 & 8 & Dog & Anjing & Asu & Asu \\
\hline 8 & 12 & Smoke & Asap & Rambu & Rumbu \\
\hline 9 & 13 & Cloud & Awan & Awan & Awang \\
\hline 10 & 16 & Burn & Bakar & Tunu & Tunu \\
\hline 11 & 17 & Return & Balik & Balik & $\mathrm{B}(/ \mathrm{w} /) \mathrm{ali}^{\prime}$ \\
\hline 12 & 21 & New & Baru & Barrung & $\mathrm{B}(/ \mathrm{w} /)$ aru \\
\hline 13 & 23 & Stone & Batu & Batu & Batu \\
\hline 14 & 26 & Correct & Benar & Tongan & Tongang \\
\hline 15 & 27 & Seed & Bibit & Banne & Bine \\
\hline 16 & 28 & Swollen & Bengkak & Kambang & Kambang \\
\hline 17 & 34 & If & Bilamana & Kenna & Tenna \\
\hline 18 & 36 & Star & Bintang & Bintoen & Bittoeng \\
\hline 19 & 38 & Moon & Bulan & Bulan & Bulang \\
\hline 20 & 39 & Feather & Bulu & Bulu & Bulu \\
\hline 21 & 40 & Flower & Bunga & Bunga & Bunga \\
\hline 22 & 41 & Kill & Bunuh & Patei & Patei \\
\hline 23 & 43 & $\mathrm{Bad}$ & Buruk & Kadake & Arae \\
\hline 24 & 45 & Putrid & Busuk & Bosi & Bosi \\
\hline 25 & 47 & Kiss & Cium & Udung & Urung \\
\hline 26 & 48 & Wash & Cuci & Sassak & Sassa \\
\hline 27 & 50 & And & Dan & $\mathrm{Na}$ & Anna \\
\hline 28 & 52 & Blood & Darah & Rara & Cera' \\
\hline 29 & 55 & Leaf & Daun & Daun & Daung \\
\hline 30 & 57 & With & Dengan & Sola & Siola \\
\hline 31 & 58 & Listen & Dengar & Parrangngi & Irrangngi \\
\hline 32 & 63 & Stand & Diri (Ber) & Ke'dek & Ke'de' \\
\hline 33 & 66 & Push & Dorong & Sorong & Sorong \\
\hline
\end{tabular}




\begin{tabular}{|c|c|c|c|c|c|}
\hline 34 & 67 & Two & Dua & Dua & Da'dua \\
\hline 35 & 70 & Four & Empat & A'pa' & Appe' \\
\hline 36 & 73 & Salt & Garam & Sia & Sia \\
\hline 37 & 75 & Fat & Gemuk & Malompo & Marumbo \\
\hline 38 & 79 & Mountain & Gunung & Buntu & Buttu \\
\hline 39 & 84 & Life & Hidup & Tuo & Tuo \\
\hline 40 & 87 & Black & Hitam & Lotong & Lotong \\
\hline 41 & 88 & Account & Hitung & Reken & Rekeng \\
\hline 42 & 89 & Rain & Hujan & Uran & Urang \\
\hline 43 & 91 & He/She & $\mathrm{Ia}$ & Ia & Ia \\
\hline 44 & 92 & Mother & $\mathrm{Ibu}$ & Indo & Kindo \\
\hline 45 & 95 & Wife & Istri & Baine & Baine \\
\hline 46 & 104 & Foot & Kaki & Le'te & Lette \\
\hline 47 & 107 & You & Kamu & Iko & I'o \\
\hline 48 & 108 & Right & Kanan & Kanan & Kanang \\
\hline 49 & 109 & Because & Karena & Saba' & Saba' \\
\hline 50 & 110 & Say & Kata (ber) & Nakua & Ma'ua \\
\hline 51 & 113 & Head & Kepala & Ulu & Ulu \\
\hline 52 & 115 & Left & Kiri & Kiri & Kaeri \\
\hline 53 & 117 & Nail & Kuku & Kuku & Kanuku \\
\hline 54 & 118 & Skin & Kulit & Kuli' & Uli' \\
\hline 55 & 119 & Yellow & Kuning & Mariri & Mariri \\
\hline 56 & 120 & Louse & Kutu & Kutu & Utu \\
\hline 57 & 122 & Sky & Langit & Langi' & Langi' \\
\hline 58 & 123 & Sea & Laut & Tasi' & Sasi' \\
\hline 59 & 126 & Man & Lelaki & Muane & Naimuane \\
\hline 60 & 129 & Tongue & Lidah & Lila & Lila \\
\hline 61 & 130 & See & Lihat & Kitai & Ma'ita \\
\hline 62 & 131 & Five & Lima & Lima & Lima \\
\hline 63 & 133 & Straight & Lurus & Maruru & Maroro \\
\hline 64 & 135 & Play & Main & Maningo & Mangino \\
\hline 65 & 136 & Eat & Makan & Kumande & Umande \\
\hline 66 & 137 & Night & Malam & Bongi & Bongi \\
\hline 67 & 138 & Eyes & Mata & Mata & Mata \\
\hline 68 & 139 & Sun & Matahari & Mata Allo & Mata Allo \\
\hline 69 & 140 & Die & Mati & Mate & Mate \\
\hline
\end{tabular}




\begin{tabular}{|c|c|c|c|c|c|}
\hline 70 & 146 & Vomit & Muntah & Lua & Tilua \\
\hline 71 & 147 & Name & Nama & Sanga & Sanga \\
\hline 72 & 148 & Breath & Nafas & Nawa & Nawa \\
\hline 73 & 150 & Human & Orang & Tau & Tau \\
\hline 74 & 156 & Squeeze & Peras & Parra & Perre' \\
\hline 75 & 157 & Woman & Perempuan & Baine & Naiwaine \\
\hline 76 & 159 & Think & Pikir & Pikkiri & Pikkiri \\
\hline 77 & 163 & Navel & Pusar & Posi' & Posi' \\
\hline 78 & 165 & Hair & Rambut & Belua & Bilua' \\
\hline 79 & 167 & One & Satu & Misa' & Mesa \\
\hline 80 & 170 & Day & Siang & Allo & Allo \\
\hline 81 & 172 & Narrow & Sempit & Sippik & Sippi' \\
\hline 82 & 173 & All & Semua & Yanasang & Nasang \\
\hline 83 & 174 & Husband & Suami & Muane & Muane \\
\hline 84 & 175 & River & Sungai & Salu' & Salu' \\
\hline 85 & 176 & Sharp & Tajam & Matarang & Matarang \\
\hline 86 & 178 & Year & Tahun & Tahun & Taung \\
\hline 87 & 181 & Land & Tanah & Lita' & Lita' \\
\hline 88 & 182 & Hand & Tangan & Lima & Lima \\
\hline 89 & 184 & Thick & Tebal & Makambang & Maumbang \\
\hline 90 & 185 & Ear & Telinga & Talinga & Talinga \\
\hline 91 & 186 & Egg & Telur & Tallo & Tallo \\
\hline 92 & 188 & Laugh & Tertawa & Metawa & Micawa \\
\hline 93 & 189 & Breast & Tetek & Susu & Susu \\
\hline 94 & 192 & Three & Tiga & Tallu & Tallu \\
\hline 95 & 194 & Thin & Tipis & Manipping & Manipis \\
\hline 96 & 196 & Cane & Tongkat & Tekken & Te'eng \\
\hline 97 & 198 & Bone & Tulang & Buku & Buku (-buku) \\
\hline 98 & 200 & Snake & Ular & Ulak & Ular \\
\hline
\end{tabular}

\section{b. Percentage of Kinship between Torajanese and Mandarese}

Based on the data, the researher found there are 98 cognates. Besides, there are 102 difference words. So, the presentation of differences between Torajanese and Mandarese is as below:

$$
\begin{aligned}
\mathrm{D} & =102 / 200 \times 100 \% \\
& =51 \%
\end{aligned}
$$


Based on lexicostatistic, the researchers categorized these languages into "Dialect differences". Although they have some differences, Torajanese and Mandarese still shared many same words. That is why Torajanese can understand Mandarese from listening to its utterances and vice versa.

\section{c. Particular Sound Change from Torajanese Language to Mandarese Language}

There are some particular sound changes from Torajanese as proto-language into Mandarese as branch of Torajanese language. They change automatically as adaptation process toward the vocal cord and nature of Mandarese. Here are the lists of that sound changes:

1) Apharesis

\begin{tabular}{|c|c|l|l|l|l|}
\hline Number & Code & English & Indonesian & Torajanese & Mandarese \\
\hline 1 & 43 & Bad & Buruk & Kadake & Arae' \\
\hline 2 & 118 & Skin & Kulit & Kuli' & Uli' $^{\prime}$ \\
\hline 3 & 120 & Louse & Kutu & Kutu & Utu \\
\hline 4 & 134 & Knee & Lutut & Guntu & Utti' \\
\hline 5 & 136 & Eat & Makan & Kumande & Umande \\
\hline
\end{tabular}

2) Syncope

\begin{tabular}{|c|c|l|l|l|l|}
\hline Number & Code & English & Indonesian & Torajanese & Mandarese \\
\hline 1 & 4 & I & Aku & Aku' & Iau \\
\hline 2 & 43 & Bad & Buruk & Kadake & Arae' \\
\hline 3 & 110 & Say & Kata (ber) & Nakua & Maua \\
\hline 4 & 184 & Thick & Tebal & Makambang & Maumbang \\
\hline
\end{tabular}

3) Lenition

\begin{tabular}{|c|c|l|l|l|l|}
\hline Number & Code & English & Indonesian & Torajanese & Mandarese \\
\hline 1 & 56 & Near & Dekat & Mandappik & Kareppu' \\
\hline 2 & 63 & Stand & Diri (ber) & Ke'dek & Ke'de' \\
\hline 3 & 71 & You & Engkau & Iko & I'o \\
\hline 4 & 110 & Say & Kata (ber) & Nakua & Ma'ua \\
\hline 5 & 130 & See & Lihat & Kita & Ma'ita \\
\hline 6 & 196 & Cane & Tongkat & Tekken & Te'eng \\
\hline 7 & 21 & New & Baru & Barrung & Baru \\
\hline 8 & 17 & Return & Balik & Balik & Bali' \\
\hline 9 & 109 & Because & Karena & Saba' & Saba' \\
\hline
\end{tabular}




\begin{tabular}{|c|c|l|l|l|l|}
10 & 157 & Woman & Perempuan & Baine & Naiwaine \\
\hline 11 & 34 & If & Bilamana & Kenna & Tenna \\
\hline 12 & 12 & Smoke & Asap & Rambu & Rumbu \\
\hline 13 & 184 & Thick & Tebal & Makambang & Maumbang \\
\hline 14 & 3 & Root & Akar & Waka' & Uwake' \\
\hline 15 & 52 & Blood & Darah & Rara & Cera' \\
\hline 16 & 70 & Four & Empat & A'pa' & Appe \\
\hline 17 & 95 & Wife & Istri & Baira & Baine \\
\hline 18 & 156 & Squeeze & Peras & Parra' & Perre' \\
\hline 19 & 75 & Fat & Gemuk & Malompo & Marumbo \\
\hline 20 & 27 & Seed & Benih & Banne & Bine \\
\hline
\end{tabular}

4) Fortition

\begin{tabular}{|c|c|l|l|l|l|}
\hline Number & Code & English & Indonesian & Torajanese & Mandarese \\
\hline 1 & 75 & Fat & Gemuk & Malompo & Marumbo \\
\hline 2 & 133 & Straight & Lurus & Maruru & Maroro \\
\hline 3 & 197 & Old & Tua & Matua & Toa \\
\hline 4 & 43 & Bad & Buruk & Kadake & Arae \\
\hline 5 & 47 & Kiss & Cium & Udung & Urung \\
\hline 6 & 56 & Near & Dekat & Madappik & Kareppu \\
\hline
\end{tabular}

5) Prothesis

\begin{tabular}{|c|c|l|l|l|l|}
\hline Number & Code & English & Indonesian & Torajanese & Mandarese \\
\hline 1 & 29 & Swim & Berenang & Norong & Ummmorong \\
\hline 2 & 50 & And & Dan & Na & Anna \\
\hline 3 & 59 & In & Di dalam & Lan & Dilalang \\
\hline 4 & 67 & Two & Dua & Dua & Da'dua \\
\hline 5 & 126 & Man & Lelaki & Muane & Naimuane \\
\hline 6 & 157 & Woman & Perempuan & Baine & Naiwaine \\
\hline 7 & 146 & Vomit & Muntah & Lua & Tilua \\
\hline
\end{tabular}

6) Vowel Breaking

\begin{tabular}{|c|c|l|l|l|l|}
\hline Number & Code & English & Indonesian & Torajanese & Mandarese \\
\hline 1 & 57 & With & Dengan & Sola & Siola \\
\hline 2 & 72 & Dig & Gali & Kali' & Karoi \\
\hline 3 & 115 & Left & Kiri & Kiri & Kaeri \\
\hline
\end{tabular}


7) Assimilation

\begin{tabular}{|c|c|l|l|l|l|}
\hline Number & Code & English & Indonesian & Torajanese & Mandarese \\
\hline 1 & 36 & Star & Bintang & Bintoen & Bittoeng \\
\hline 2 & 79 & Mountain & Gunung & Buntu & Buttu \\
\hline 3 & 134 & Knee & Lutut & Guntu' & Utti' \\
\hline 4 & 104 & Foot & Kaki & Le'te & Lette \\
\hline 5 & 70 & Four & Empat & A'pa' & Appe' \\
\hline 6 & 29 & Swim & Berenang & Norong & Ummorong \\
\hline 7 & 126 & Man & Lelaki & Muane & Naimuane \\
\hline 8 & 157 & Woman & Perempuan & Baine & Naiwaine \\
\hline
\end{tabular}

Some of the above tables show that the change of voice from Torajanes to Mandarese occurs in several types of changes with varying amounts. The most dominant change is the lenition where some strong sounds is changed to weaker sound such as $/ \mathrm{k} /$ to $/ \%$. The examples are in the words $k e^{\prime} d e k$ to $k e^{\prime} d e^{\prime}$; iko to i'o; nakua to ma'ua; kita to ma'ita; tekken to te'eng; and balik to bali '. Besides, lenition also occurs in vowel sounds such as /a/ to /e/ in the words rara to cera'; a'pa 'to appe'; and parra' to perre'.

\section{REFERENCES}

Crowley, Terry. 1997. An Introduction to Historical Linguistics ( $3^{\text {rd }}$ Edition). Oxford: Oxford University Press.

Darmawati. 2014. Kalili Language in Torajanese Language: A Trace of Austronesian Languages in the Archipelago. Sawerigading Journal: Volume 20, Number 2, Page 227-238.

Keraf, Gorys. 1991. Linguistik Bandingan Historis. Jakarta: PT Gramedia Pustaka Utama.

The Digitized La Galigo Manuscript. 2017. Accessed at http://digitalcollections.universiteitleiden.nl/LaGaligo on August, $20^{\text {th }} 2017$.

Masinambouw, E.K.M, et.all. 2004. Polemik tentang Masyarakat Austronesia: Fakta atau Fiksi? Jakarta: Lembaga Ilmu Pengetahuan Indonesia.

Mattulada. 1974. Manusia Bugis-Makassar. A paper presented at Literature Faculty of Indonesia University and LIPI on June 1974.

Samantho, Ahmad Yanuana. 2015. Atlantis Nusantara. Jakarta: Phoenix.

Yatim, Nurdin., and Hamzah Machmoed. 2007. Distribusi Bahasa Duri dan Bahasa Toraja: Suatu Analisis Geografi Dialek. Linguistik Indonesia: Volume 25, Number 1, Page 35-49. 